Article

\title{
"THE TYPICAL GHADAR OUTLOOK": UDHAM SINGH, DIASPORA RADICALISM, AND PUNJABI ANTICOLONIALISM IN BRITAIN (1938-1947)
}

\author{
SILAS WEBB
}

Syracuse University

\begin{abstract}
Punjabis in interwar Britain, who had migrated for economic opportunity but had been politicized during successive upheavals at home, admired Ghadar's radical solidarities with nationalist and anticolonial movements. This article focuses on peripatetic Punjabi radicals, often working as pedlars and sailors, to enhance the current understanding of the vibrant relationship between the Ghadar Party and Punjabis in Britain. This article contextualizes Udham Singh's martyrdom by examining the uses to which his name and image were put in radical publications. Furthermore, the Indian Workers' Association, formed in the midst of the Second World War, was integral to articulating a Ghadarite anticolonialism in Britain, which was animated by the trial and memorialization of Udham Singh. Thus, this article argues that labor migration and the global transmission of Ghadar Party publications was integral to the Ghadar movement's influence on the struggle against imperialism in Britain in the 1930s and 1940s.
\end{abstract}

\section{Keywords}

Udham Singh; Indian Workers' Association; anticolonialism; labor militancy; Britain; Punjab

On the morning of 13 March 1940, a Wednesday, Udham Singh had planned to visit the India Office to see about getting a travel endorsement for his passport. But Sir Hassan Suhrawardy, advisor to the Secretary of State for India, was out, and Singh decided he had better things to do than queue for a colonial official. On his way out the door, he glanced at a notice about a joint meeting of the East India Association and the Central Asian Society being held later that day at the Caxton Hall in London. His interest was piqued enough to remember the details, or perhaps he wrote them down, but not quite enough to change his plan for the day. Later, he told police, "when I left home today I thought I would go see the Paul Robeson picture in the Leicester Square" (Azad 13 March 1940, MEPO 3/1743). But, as luck would have it, the cinema had not yet opened when he arrived. So, instead of viewing Paul Robeson's The Proud Valley, he went home, retrieved his .44 caliber Smith \& Wesson revolver, and walked to the Caxton Hall. On arrival, he stood in the side aisle of a capacity Tudor Room, waited until the end of the remarks and approached the stage 
with gun drawn. He discharged six bullets, one each into Lord Lamington, the Marquess of Zetland, and Sir Louis Dane, and two in the back of former Lieutenant-Governor of Punjab Sir Michael O'Dwyer, whose tenure oversaw the Amritsar Massacre in 1919, killing him in an instant.

The assassination of Michael O'Dwyer was an act of revolution and it was a product of the militant political philosophy of the Ghadar Party. Yet, much of the literature on Ghadar traces the short term impact of its failure without investigating the ways in which Ghadris continued to struggle against British rule up until the end of World War II (Juergensmeyer 1977; Puri 1983; Ramnath 2011; Upadhyay 2014). By focusing on the immediate ramifications of the failed mutiny, such scholarship neglects the global resonance that Ghadar had within the Indian diaspora. In the 1930s, Punjabi left politics was characterized by fluidity between Ghadarites, Communists, and Congressmen, which radicalized peasant politics in Punjab (Mukherjee 2004, 45; Raza 2013, 322). As this article demonstrates, Punjabis in interwar Britain, many of whom had migrated for economic opportunity but had been politicized during successive upheavals at home, admired Ghadar's radical solidarities with nationalist and anticolonial movements. Such peripatetic Punjabi radicals, often working as pedlars and sailors, illustrate how movement between India and Britain sustained the Ghadar Party for decades after its foundational failure.

This article focuses on these travelers and migrants to enhance the current understanding of the influence that the Ghadar Party had on Punjabis in Britain. Rattan Singh, who liaised between the Ghadar Party and the Communist International and established Ghadar Parties on three continents, was integral to Ghadar mobilization in Britain by corresponding with aspiring revolutionaries in Britain. Udham Singh had a twenty year career of traveling between India, Britain, and the United States, during which he committed himself to Ghadar militancy and was memorialized as a martyr for Indian independence. The Indian Workers' Association, with which the article concludes, was the organizational embodiment of the Ghadar Party in Britain and was established by pedlars and semi-skilled workers who were enamored by the examples of Kartar Singh Sarabha, Bhagat Singh, Udham Singh, and countless of their relatives and neighbours who had been jailed, transported, or executed while resisting colonial rule in Punjab. By foregrounding the importance of mobility, and examining complementary events in South Asia and Britain, this article argues that labour migration between India and Europe and the global transmission of Ghadar Party publications were integral to the Ghadar movement's influence on the struggle against imperialism in Britain in the 1930s and 1940s.

The Indian migrants, whose stories, affiliations, and politics fill the following pages are not, for the most part, well-known to history. In the interest of reconstructing their networks and their struggle, I have made considerable recourse to surveillance and police documents because these are not individuals who were widely covered by the press nor did they bequeath their libraries and personal papers to archives. Nevertheless, I have made every attempt to use the intelligence apparatus in order to demonstrate the agency and intentionality of Indian migrant pedlars and workers in Britain rather than to rehearse the frantic search for a "Bolshevik Menace" that animated the official mind during the fraught years after the Russian Revolution of 1917. Thus, I have deployed the meticulous information gathering that the Metropolitan Police and the Indian 
Political Intelligence service conducted to reconstruct the kinds of "affective communities" that Indians created abroad in pursuit of economic opportunity and anticolonial mobilization (Gandhi 2006). Characterizations of their politics or movement as extremist or devious by the intelligence community are instructive not only in terms of how they were perceived by the state, but also, and more importantly, because these documents reveal much about the materiality of migration. It is in that latter sense that I hope my use of government archives will be understood.

\section{"Fighting the 'enemy' in the proper way"}

The preponderance of South Asian lascars, pedlars, and students in Britain, rather than the farmers and soldiers that Ghadar ordinarily recruited, was alone sufficient to convince party leaders that expansion into Britain was untenable ("Report on Ghadr Party" 10 May 1939, IOR/L/PJ/12/285). The Ghadar Party of the late-1930s was a highly centralized, global organization that had been disciplined through cooperation and coordination with the Communist International and the University of the Toilers of the East in Moscow. As a result, the majority of Ghadris recruited in the interwar period came from established networks in South Asia, East Africa, South America, and California. The distance that these networks created between Ghadar and Indians in Britain, combined with the lack of effective mobilization of Indians by local political organizations, particularly the Communist Party of Great Britain and the Labour Party, which fueled their reputation as apolitical merchants, helps to explain the refusal of official expansion of the Ghadar Party into the colonial metropole. Yet, this skepticism about the mettle of Indians in Britain not only failed to deter Ghadar-inspired Punjabis from organizing eventually, if independently, but also revealed a thorough misunderstanding of the influence that homeland politics and anticolonial agitation had on enclaves of zealous Punjabis in Britain.

In her Echoes of Mutiny, Seema Sohi emphasizes the important ways in which Indians were incorporated into, and victimized by, global market capitalism in the first two decades of the twentieth century (Sohi 2014, 14-16). The creation of Indian migrant workers in the early twentieth century was an effect of colonial agricultural policies that maintained persistent undercapitalisation on Indian farms, particularly in Punjab, that fed into a cycle of debt and dispossession (Davis 2002, 312; Mann 2015, 173). Not only had small farmers been undermined by revenue systems that led to the concentration of farmland into fewer hands, but also the land promised to demobilized soldiers as a reward for service was dwindling. These policies had profound effects on Punjabi small peasants and contributed significantly to the emergence of a Punjabi diaspora, which, by the end of World War I, stretched from Hong Kong and Shanghai to the Pacific Northwest, Argentina, and Europe. Of particular interest for my argument are the forms of migration to Britain and the ways in which politics are produced through experiences before, during, and after migration. Sohi's conclusions about the politicization of Punjabi migrants in North America are instructive but insufficient for understanding early Punjabi migration to 
Britain in the 1920s. The later wave of migrants to Britain had been politicized by nationalist and anticolonial insurgencies in Punjab that were buttressed by the returned Ghadar babas and they reproduced the changed political landscape of their homelands in the ports and industrial cities of Britain.

The two methods of escaping agricultural hardship in interwar Punjab that led to Britain were employment in the Merchant Marine and establishment of pedlar networks. Systems of recruitment into the Merchant Marine had become highly sophisticated by the end of World War I. According to Ravi Ahuja, recruitment of Indian seamen, typically called lascars, was facilitated by "spatial centralization" in the ports of Bombay and Calcutta. Moreover, zones of military recruitment in Western Punjab, particularly Rawalpindi and Attock, were gradually transformed into recruitment grounds for Muslim engine-room crews for shipping companies (Ahuja 2002, 47-49). Central Punjab, an area populated heavily by Sikhs, did not become a locus of recruitment into the Merchant Marine; however, the economic stagnation of the 1930s compounded longstanding issues around access to land in this fertile region led many Punjabis from Hoshiarpur, Jalandhar, and Ludhiana to use family and village networks to establish themselves as pedlars in places like Reading, Coventry, and Glasgow (Ballard and Ballard 1977, 21).

Although many of the Punjabi migrant workers who came to Britain in the interwar period came from central Punjab, a region described in 1942 as a "hotbe[d] of political agitation," their residence in Britain kept them out of Ghadar's established recruiting networks ("Proposed inclusion of certain Indians on the Suspect List" 15 May 1942, IOR/L/PJ/12/646). In 1922, the Ghadar Party forged a partnership with the Comintern's University of the Toilers of the East (KUTV) so that Ghadar Party members could receive formal education in revolutionary history, trade unionism, and military and vocational training (Mukherji 2011, 41-42). Over the course of this relationship there were two primary modes of recruitment to the KUTV. In the first instance, the Ghadar Party supplied the majority of the Comintern's Indian students from Argentina (Mukherji 2011, 68; Josh 1977, 28). In the second mode, beginning in 1936, the Comintern resolved that all Indians were to be enlisted in India and then sent to Moscow via "devious" routes: "These youths are to find their way from India in the first instance either to North or South America in the guise of labourer or to England as students. From these countries arrangements will then be made to send them to Moscow" (IPI Report on Ghadar Party. 3 November 1936, IOR/L/PJ/12/285, File 1392(A)/25). Importantly, this approach made Britain a central thru-point for Indian recruits, but in neither approach was Britain deemed an appropriate site for recruitment.

Any consideration of interwar migrant politics must acknowledge the distance between British political parties and colonial migrants in British cities. The Communist Party of Great Britain (CPGB) and its anticolonial work, especially whether it remained aloof from the colonies due to the working-class racism, or if it was, in fact, integral to the Indian independence movement, has been the subject of some debate (Sherwood 1996; Callaghan 1998; Smith 2008). Though the CPGB and the Red International of Labour Unions supported the International and Oriental Seafarer's Union and sought to use Indian seamen in European ports to smuggle arms and propaganda into India, both efforts were short-lived and non-systematic ("Indians in London" 25 
May 1923, IOR/L/PJ/12/143; “DIB Report” July 1923, IOR/L/PJ/12/54, File 4968(C)/21). By attempting to segregate initiatives directed at British socialism and anti-colonialism, Indian workers in Britain were overlooked as potential Party members in the early 1920s and remained outside of the CPGB ambit until the period of mass migration in the 1950s. The inability or unwillingness of British political parties to recruit and incorporate Indian migrant workers into their ranks in the early interwar period contributed to the slow pace of political organization among migrants.

In interwar India the organized Left had contributed to making Punjab a site of revolutionary politics; yet, Indians in Britain have remained marginal to the debate surrounding the interaction between the British left and the struggle against imperialism. As London, Coventry, and Birmingham became bridgeheads for Indian settlement in the late-1930s, they were also provided with the opportunity to mobilize around community-specific issues, especially military conscription. While mutiny is foundational to Ghadar Party lore, and remained an animating force throughout the period, by 1937 the march to war had led to a new kind of military disruption in the form of anti-recruitment meetings in Punjab (Sharma 2010, 85). At the same time, Punjabi migrants in Britain were beginning to organize around the same principle and soon joined up with the Independent Labour Party, a staunch critic of the war ("Indian Notes September-October 1942", IOR/L/PJ/12/646). The confluence of settlement and increased participation in local political organizations provided a foundation that partially facilitated the emergence and articulation of Ghadarite zeal in Britain previously untapped because of ineffective political leadership and mobilization.

In May 1939, Charan Singh Chima, a Punjabi Sikh in Coventry who was "anxious to start a Ghadr [sic] Party group in the U.K," wrote on behalf of "four or five young men of his way of thinking" to Rattan Singh, one of the leading lights of the interwar Ghadar Party, for guidance on establishing a branch in Britain ("Report on Ghadr Party" 10 May 1939, IOR/L/PJ/12/285). Rattan Singh, listed as R-36 in the Ghadr Directory (1934), was "one of the most active and dangerous leaders of the Ghadr movement" (Intelligence Bureau 1934, 252). Chima was aware of Rattan Singh both due to his leadership role within the Ghadar Party and because of close family connections. Charan Singh Chima's uncle, Karam Singh Chima, had participated in the failed revolution of 1914 and, though restricted to his village, was an integral link between the Akali and Kirti movements in Punjab. For instance, in 1920 he was jailed for "fomenting Akali agitation" in Jullundur, and in 1924 he was arrested for serving on the Shiromani Gurdwara Parbhandak Committee, an Akali organization which had been banned. Subsequently, in 1927, he became the Vice-President of the Desh Bhagat Parwar Sahaik (Patriot Family Fund) Committee, which supported the families of Ghadarites who had been imprisoned, deported, or executed (Intelligence Bureau 1934, 154-56). Karam Singh Chima's overlapping political and social affiliations was unsurprising in a period of considerable upheaval. The strength of the Ghadar party, as well as the salience of Punjabi communism in the 1930s, was due in large part to the ability of its members to negotiate multiple alliances and leverage them for particular political ends (Sharma 2010, 3; Mukherjee 2004, 105). 
In the late-1930s, a period when attempted unionization of sailors and factory workers was the primary mode of associational politics for Indians in Britain, Chima and his colleagues sought to harness the power of Ghadar to mobilize Indian migrant workers against imperialism, conscription, and unfair working conditions. Charan Singh Chima and his associates in the English Midlands had been raised in the ferment of Ghadar-Akali-Kirti agitation of the 1920s and early-1930s and upon arrival in Britain sought to contribute to these struggles. Yet, Rattan Singh did not enthusiastically endorse their goals because he believed that there were not enough Indians in Britain who were willing and able to participate in the struggle "in the proper way." Nonetheless, he suggested that Charan Singh Chima organize an "Indian Political Prisoners' Defence Committee," which was clearly inspired by, and potentially modeled on, Karam Singh Chima's Patriot Family Fund ("Report on Ghadr Party" 10 May 1939, IOR/L/PJ/12/285).

A few months later, Charan Singh Chima wrote to Rattan Singh and intimated that he had abandoned his plans to organize a distinct association but hoped to collect funds for remittance to Punjab from among the Punjabis in the Midlands and would endeavor to continue "studying the History of the Russian Communist Party" ("Report on Ghadr Party" 3 November 1939, IOR/L/PJ/12/285). Not only had Rattan Singh dissuaded Charan Singh Chima from establishing a Ghadar Party branch in the United Kingdom but also the onset of war thoroughly delayed any ideas of contributing to the militant struggle for Indian Independence in Britain. However, Punjabis in Britain were politically mobilized and the prospect of directly engaging with the Ghadar movement was reanimated in the midst of the trial, appeal, and execution of Udham Singh, to which this article will now turn.

\section{"I bought the revolver from a soldier in Bournemouth": Udham Singh's revolution}

Udham Singh occupies a contested place in Sikh, Punjabi, and Ghadar history. His singular act of political assassination has been dismissed as a "random incident" by a "vagrant Sikh," and his execution is often considered in the context of Sikh martyrdom (Tatla 1999, 91; Fenech 2002). Though Udham Singh's treatment as "shaheed" by historians of the Sikh diaspora reflects the legitimate embrace of a noteworthy Punjabi by the Sikh community, enhanced by his welldocumented interaction with Sikhs at the Gurdwara in Shepherds Bush, London, such a representation reduces him to an ethnic identity and ignores his own statements about his political allegiances and his religious proclivities. Rather than a spontaneous act of individual terrorism, documents from the Home Office, India Office, and Metropolitan Police demonstrate that Udham Singh systematically targeted Michael O’Dwyer and other colonial administrators, revealing a deep attachment to the Ghadar Party and revolutionary anticolonialism (Singh 2007; Stadtler 2012).

Like many Punjabi migrants in Britain during the interwar period, Udham Singh came to Britain and earned his living as an itinerant merchant. He arrived in 1933 and, in 1934, the Metropolitan Police confirmed that "Udam Singh Sidhu," of 9 Adler Street, Stepney, London, had been granted a Pedlars Certificate in December (Metropolitan Police 5 December 1934, MEPO 
2/5064). In 1937, police investigations revealed that "Udham Singh peddles hosiery and lingerie and uses a small car for the purpose; he does not appear to be short of money" (IPI to Mr. Silver 22 November 1937, MS2142/B/3/3). Peddling was a common occupation for Indian migrants in the interwar period because they were largely kept out of industrial work until the labour shortage that accompanied the onset of war and in 1934 this area of Stepney was home to "a large colony of British Indians." 9 Adler Street, a common lodging house, was among the many nodes of the Punjabi pedlar fraternity. According to Inspector L. Clark, nine British Indians had applied for Pedlars Certificates from this address in 1934, with five, including Udham Singh's, being granted. The building was a ramshackle former shop, where, "with the exception of a small portion left uncovered and painted, presumably to admit light, the shop window of No. 9 is permanently shuttered." When questioned by police, Banta Singh, the building manager, stated that the men who lived there were effectively self-employed pedlars who "as a rule purchase their goods from the local wholesalers and arrange their own sales" (Clark 26 January 1934, IOR/L/PJ/7/1007).

After a few lines deriding the residents of 9 Adler Street, characterizing them as "huddled as far as there was room" and "as being men of low intelligence and social order" appearing "unmistakably dejected and dismal," Inspector Clark noted that Indians were attracted to this part of Stepney largely because "the predominating Jewish population do not object to their presence" (Clark 26 January 1934, IOR/L/PJ/7/1007). Thus, to use Earl Lewis's (1995) felicitous phrase, Stepney was a neighborhood comprised of "overlapping diasporas." Here, Indians and Eastern European Jews created a community that was emblematic of Udham Singh's overarching commitment to the international labour movement and the degree to which he was able to transgress the boundaries of ethnicity. While explaining his chosen name to Divisional Detective Inspector John Swain, after he had been detained in Caxton Hall, Singh recalled that "when I was seven I call myself Mohamed Singh. I like Mohamedan religion and I try to mix with Mohamedans" (Swain 16 March 1940, MEPO 3/1743). Later, while testifying during his trial, he underscored his interest in moving beyond the Sikh and Punjabi communities in Britain: "I have nothing against the English people at all. I have more English friends living in England than I have in India. I have great sympathy with the workers of England. I am against the Imperialist Government" (Singh 5 June 1940, MEPO 3/1743). Prior to the events of March 1940, while living in Punjab in 1927, he proclaimed that "he had intended to murder Europeans who were ruling over India and that he fully sympathized with the Bolshevics [sic], as their object was to liberate India from foreign control" (Intelligence Bureau 1934, 267). Indeed, while staying in Bournemouth in late 1939, where he bought the revolver he used against O'Dwyer, he was known as an outspoken revolutionary and described as having "strong Communistic views" (Hants Constabulary 23 March 1940, MEPO 3/1743).

Emboldened by Soviet propaganda and the emphasis on military training from University of the Toilers of the East in Moscow, the Ghadar Party of the 1930s was newly determined to covertly arm Indians and start a revolution. Fear of arms smuggling was a high priority for the British authorities surveilling Ghadarites. In 1915, during the attempt to foment a mutiny among 
Sikh troops in India, the Ghadar Party enlisted two ships, the Annie Larsen and the Maverick, to illegally transport guns (Bains 1962, 51). Twenty years later, after enlisting the help of Soviet tacticians, the City of Christchurch, a steamship, had been seized by police in Calcutta with a cache of arms and noted that "the Indian police have an idea that Gadaries [sic] are secretly gathering arms" (Hindustan Ghadr September 1940, IOR/L/PJ/12/757). In 1927, the intelligence apparatus was keen to learn that Udham Singh was arrested on 30 August under Section 20 of the Arms Act, which perceived his possession of two revolvers, one pistol, ammunition, and "copies of the prohibited paper, Ghadr-di-Gunj" as an attempt to smuggle weapons (Swain 16 March 1940, 3/1743). Udham Singh's subsequent arrest highlights the fact that his radicalization was the product of a long engagement with the revolutionary politics of the Soviet Union and Ghadar Party.

Indian communities throughout Britain and North America were mobilized in support of Udham Singh after his arrest and arraignment. Usually focused on the welfare of Indian seamen in British ports, Surat Ali, a Bengali ex-lascar, initially garnered support for Udham Singh by collecting funds for his defense (IPI to Mr. Silver 21 March 1940, MS2142/B/3/3). As the campaign to raise funds for Singh's defense began in Britain, the Sikh Temple in Stockton, California, a wellestablished wing of the Ghadar Party, sent a telegram to Indian representatives in London to enquire about the arrangements for Singh's legal counsel. Even though there was "no evidence whatever of recent direct communication between him and the Party," Udham Singh instructed his solicitor, Robert Clayton, to respond to the Sikh Temple and assured him that it "would bring in anything up to $£ 1,000$ " (IPI to Mr. Silver 23 April 1940, MS2142/B/3/3). Engaging the Ghadar Party for funds seems to have irritated some Indians connected with Udham Singh's representation, but it was not, as Robert Clayton had understood, the result of a feud between Sikhs in the UK and those in California. In the India Office's view, "there is no reason to suppose that anything in the nature of a feud exists" but "the United Kingdom Sikhs are doubtless not anxious to give the appearance of having relations with a body so notorious as is the Ghadr Party" (IPI to Mr. Silver 23 April 1940, MS2142/B/3/3). Rather, the feud appears to have been between Krishna Menon and Surat Ali, both of whom vied to represent Singh. Ultimately, the Stockton Temple cabled $£ 150$ as an endorsement of Udham Singh's act and with a view to buttress the movement through coverage of the trial ("Udham Singh Case" 11 July 1940, MS2142/B/3/3).

As early as June, the India Office appeared convinced both of the political salience of Udham Singh's case among Sikhs and the utter lack of interest from the rest of the Indian community in Britain. To that end, the Office suspected that the Sikhs would seek a reprieve and, "if they failed, Udham Singh would die a martyr's death, and his photograph would be added to the...Hindustan Ghadr." However, "other sections of the Indian community in this country, of which the Sikhs form only some $20 \%$, have no sympathy for, or even interest in, the condemned man" ("Note re Udham Singh" 24 June 1940, MS2142/B/3/3). Indeed, in late July 1940, one of Udham Singh's representatives, Krishna Menon, the leader of the India League and among the most prominent Indians in Britain at the time, worked with Shiv Singh Jouhal, alternately a pedlar 
and a priest in London, to circulate a Petition for Reprieve throughout the country. Perhaps anticipating his career as an ambassador for and minister in the post-Independence Indian Government, Menon addressed the Petition to Sir John Anderson and wrote:

We, the undersigned, loyal subjects of His Majesty George the Sixth, by the Grace of God, of Great Britain, Ireland, and the British Dominions beyond the Seas, Defender of the Faith, Emperor of India, humbly pray that you see fit to recommend to His Majesty that a reprieve be granted in favour of one Udham Singh, otherwise known as Azad Singh...We fervently believe that such act of mercy, in sparing the life of the aforesaid Udham Singh, will strengthen the bonds of union between the British and Indian peoples (Petition for Reprieve, HO 144/21445).

Though Menon ultimately declined to sign the document, nearly 300 Indians, mostly Muslim and Sikh Punjabis, and a handful of non-Indians from across Britain eventually did sign the document.

A month later, Shiv Singh Jouhal had begun to distribute the Petition for Reprieve, but the India Office remained convinced that "the general view is that outside the Sikh community, very little interest is being manifested in Udham Singh's life" ("Udham Singh: Petition for Reprieve" 26 July 1940, MS2142/B/3/3). Yet, a simple tally reveals that of the Indians who signed the petition at least 150, more than half, were Muslim. Interestingly, while Udham Singh may have been "wellknown in certain Indian circles in London" and "equally well-known among Sikh pedlars who lived at Coventry, Southampton, and other places," it is remarkable that Ujagar Singh and Kartar Singh Nagra were the only two signatories from London and Coventry, respectively ("Udham Singh: Petition for Reprieve" 26 July 1940, MS2142/B/3/3). The misperception that the India Office had that Muslims lacked interest in Udham Singh's fate may have stemmed from the distinct lack of signatures from London's East End. Surat Ali, previously at pains to distance his associates from overt coordination with the Ghadar Party while raising funds for Udham Singh's defense, advised Indians in the East End, many of whom were escaped Bengali Muslim seamen, not to sign the Petition because supplying one's full name and address could have elicited unwarranted police attention to an already precarious community ("Udham Singh: Petition for Reprieve" 26 July 1940, MS2142/B/3/3). Instead, the highest number of signatures came from the Birmingham, Huddersfield, Southampton, and the Royal Air Force Camp in Melksham, underscoring that the primary activities of Punjabis in Britain as soldiers, pedlars, unskilled labour, and escaped seamen.

The moral and monetary support that he received from the Indian community in Britain did not lead to his immortalization. Surely, firing two bullets from a .44 caliber Smith \& Wesson revolver into Sir Michael O’Dwyer, former Lieutenant-Governor of Punjab, at the Caxton Hall in London on 13 March 1940 and his subsequent hanging on 31 July 1940 at the Petonville Prison, gained him notoriety. But the uses to which his name and image were put in radical publications such as the Hindustan Ghadr and Kirti made him a martyr. 


\section{Memorials and their uses: “A prominent place in the Hindustan Ghadr's picture gallery"}

The Hindustan Ghadr took a keen interest in Udham Singh's case and both helped to galvanize transatlantic support for him in the days before his trial and, after his execution, attempted to cement Udham Singh's reputation as a revolutionary icon. In May, while Udham Singh sat in Brixton Prison, the Hindustan Ghadr published an editorial comparing him to Madan Lal Dhingra, who, in 1909, assassinated Sir William Hutt Curzon Wyllie in London. It then noted that, "in the eyes of crores of inarticulate Indians, Udham Singh has attained the dignity of martyrdom" ("Report on Ghadr Party" 17 July 1940, IOR/L/PJ/12/286). The India Office was outraged that the paper would favorably compare these two incidents and present them as "worthy of emulation." Indeed, the Office suggested that it was engaging in "indirect incitement to further acts of assassination" (IPI to Mr. Silver 27 June 1940, IOR/L/PJ/12/758). Later, in the September 1940 issue, commenting on Udham Singh's execution and its ramifications for British imperial rule in India, the Paper asserted that:

The 31st July 1940 will ever be remembered in Indian history. On this day Comrade Udham Singh Ji achieved martyrdom. By hanging Comrade Udham Singh Ji the Farangis...have further augmented their oppressions. The sigh of the oppressed Indians will ultimately destroy the oppressive Farangis (Hindustan Ghadr September 1940, IOR/L/PJ/12/758.).

Underscoring the excesses of colonial rule, and the extraordinary power of the insurgent "sigh of the oppressed Indians," this article suggests that Udham Singh's execution was an example of British tyranny. The full appreciation and canonization of Udham Singh's martyrdom, however, seemed to require a different genre altogether.

Poetry was an important mode of revolutionary expression and political education throughout the Ghadar Party's history. Both the Hindustan Ghadr and the Ghadr-di-Gunj routinely published verse written by its members. Similarly, Udham Singh included some lines of "national poetry" in a prepared statement that he attempted to read before the judge sentenced him. An India Office functionary, who attended Singh's trial and who would have been familiar with Ghadar publications, remarked derisively that writing and reciting poetry was "not an uncommon hobby among Punjabis...it is in fact one of the most effective ways of influencing the ignorant and semi-ignorant, for statement of fact is made subordinate to emotion, rhythm, rhyme and the interplay of words" ("Note re Udham Singh" 24 June 1940, MS2142/B/3/3). Yet, for the Ghadar Party, the violence of colonial rule in India could only be met with violent resistance and for that reason Udham Singh was exemplary. The December 1940 issue of Hindustan Ghadr published an unsigned poem that caused an Indian Political Intelligence agent to declare that "it is a long time since the Hindustan Ghadr has appeared with anything so strongly supporting the cult of assassination" (IPI to Mr. Silver 28 January 1941, IOR/L/PJ/12/758). As an ode to revolution, 
any question of fact is secondary to the possibility of "making sinners pay the penalty." For instance:

By striking with your hand you have made the tyrants pay the penalty/a fine garland of martyrdom is place round your neck. / You are the perfect hero in the matter of freedom/ You have struck down the chains of slavery... / Hands such as yours seizing the sword / washing away the mark of slavery from the brow... / Arise, heroes, be steady / the time to introduce freedom has come. / Expel the tyrants, pacify India / there is no time left for delay. / Come, let us annihilate cruel England / you who want to introduce freedom. / Expel the cruel Farangis from your house / consider how to bring about rebellion (Hindustan Ghadr December 1940, IPI to Mr. Silver 28 January 1941, IOR/L/PJ/12/758).

Echoing the Ghadar critique of British tyranny, the poem places Udham Singh in a lineage of "the greatness of those who became martyrs for their country," which included Kartar Singh Sarabha, a Ghadarite who was executed in 1915, and Bhagat Singh, Rajguru, and Sukhdev, executed together in 1931, among others. In this way, the poet indicates that the spirit of militant anticolonialism had been embodied many times before and that Udham Singh should not be the last.

The international circulation of its publications was integral to the dissemination of Ghadar politics to Europe and India. As has been mentioned, Udham Singh was arrested in 1927 under the Arms Act, with the further incriminating evidence of his possession of copies of Ghadrdi-Gunj. In the months prior to the assassination he was evidently in "regular receipt" of the Hindustan Ghadr ("Report on Ghadr" 17 July 1940, IOR/L/PJ/12/286). These two instances of his consumption of Ghadarite publications buttress claims about Udham Singh's personal connection to the movement and his underlying revolutionary tendencies. They also indicate the ease with which these publications were distributed. Because the Ghadar Party intended to disrupt British Indian soldiers and encourage them to dessert, the India Office sought to monitor how and where their publications were distributed. In February 1942, for instance, the India Office realized that the Hindustan Ghadr had "played no small part in inducing a general atmosphere of disaffection" among Sikh soldiers in the Far East" (IPI to Mr. Silver 28 February 1942, IOR/L/PJ/12/758). Thus, even as the British authorities noted the presence of Hindustan Ghadr and Ghadr-di-Gunj, especially in such sensitive areas as war-zones, the route that the papers took was difficult to discern and, therefore, difficult to stop.

The India Office acknowledged that the effort to reduce the circulation of the Hindustan Ghadr was exacerbated because those in receipt of the paper exceeded the names on subscription rolls. In 1940, for instance, although no active subscribers lived there, the United Kingdom "receives two or three dozen copies every month." The publishers' goal, evidently, was not for the paper to garner subscription fees for the Party but simply to maximize circulation. Indeed, the 
production of the paper not only served as the Ghadar Party's principal contribution to the struggle against imperialism during World War II, but also, more fundamentally, it helped "to keep alight the flame of...extreme nationalistic ardour of Sikhs abroad" (IPI to Mr. Silver 28 February 1940, IOR/L/PJ/12/758). In Coventry, which received bundles of the paper up until at least 1947, access to the Hindustan Ghadr and the tenets of the Ghadar Party played a significant role in the political consciousness and subsequent organization of Charan Singh Chima and his clique of "extremist Sikhs," to whom this article will now return ("Report on Ghadr" 1 December 1947, IOR/L/PJ/12/286; “Review: 1942-43” 19 November 1943, IOR/L/PJ/12/646).

\section{A "band of extremist Sikhs": the formation of the Indian Workers' Association}

The Indian Workers' Association (IWA), the expatriate organization that Charan Singh Chima ultimately helped to establish after consulting with Rattan Singh in 1939, was integral to articulating an anticolonial politics in Britain that were informed by the Ghadar movement and animated by the trial and execution of Udham Singh. ${ }^{1}$ From its earliest history, the Indian Political Intelligence service was concerned that the IWA could have been a destabilizing force among Indians in the Midlands and feared that "under invasion conditions some of them, particularly the Sikhs, might present considerable danger" (IPI to Mr. Silver 15 May 1942, IOR/L/PJ/12/645). Such alarm was founded on the observation that the overwhelming majority of its members were from Hoshiarpur and Jalandhar in the central Punjab, which, the IPI was quick to note, "have for many years past been hotbeds of violent political agitation, and in fact represent the birth-place of the Ghadr Party" ("Indian Workers' Association” 14 April 1942, IOR/L/PJ/12/645). Furthermore, the Intelligence agency believed that "it is quite clear...that the leaders of the Indian Workers' Association regard it as one of their functions to educate the Indian workers in this country politically, so that when the time comes for them to return to India they may be able to take their part in the revolutionary movement." Thus, the India Office coordinated with the Home Office and Chief Constable of Birmingham to maintain a close watch on the work of the association, most of whom had congregated in the Midlands for economic opportunity.

An immediate response by the surveillance apparatus was to develop dossiers on the "leading personalities" of the association so that "disaffected Indians" might be easily interned in the event of an invasion. Of the few dozen Indians in Coventry and Birmingham who routinely attended the Association's meetings, particular attention was paid to six: Thakur Singh Basra, Charan Singh Chima, Karm Singh Overseer, Kartar Singh Nagra, Vellala Srikantappa (VS) Sastry, and Chowdry Akbar Ali Khan. A demobilized soldier, Thakur Singh Basra was known to subscribe to the Hindustan Ghadr and was reputed to have been "very prominent" in the course of raising funds for Udham Singh's defense. As already noted, Charan Singh Chima, the nephew of Karam

\footnotetext{
${ }^{1}$ Based on all available documentary evidence that I have seen, Udham Singh's relationship to the IWA was exclusively as a mobilizing icon. He was not, as Hiro (1973), Clark (1975), and Sivanandan (1981) have asserted, a foundermember of the Indian Workers' Association.
} 
Singh Chima, "one of the most prominent of the Ghadr Party leaders in the Punjab," had used his uncle's position and influence to facilitate the establishment of the IWA. Karam Singh Overseer was a devotee of Udham Singh and had held a subscription to Kirti the journal of the Kirti-Kisan Party in Punjab. Mentioned earlier as the only signatory from Coventry on Udham Singh's Petition for Reprieve, Kartar Singh Nagra subscribed to the Kirti Lehar and the Hindustan Ghadr and "had obviously been interested in revolutionary Sikh activities before he sailed from India." The only non-Punjabi in the leadership, VS Sastry, a Madrasi, worked with the IWA for the chance to educate Indians in Britain and prepare them for the militant struggle for independence in India. Finally, Chowdry Akbar Khan, who lived with Thakur Singh Basra in Coventry, was an ardent nationalist and helped Indians in Britain to avoid conscription (IPI to Mr. Silver 2 May 1942, IOR/L/PJ/12/645). Though the IPI noted that the first four men had the "typical Ghadar outlook," neither Khan nor Sastry appear to have been orthodox Ghadarites. Nonetheless, they coordinated and helped to lead the IWA because their politics overlapped with that movement in key areas, especially militant anticolonialism and the effort to undermine the British war-effort.

Public meetings served important functions for the pedagogic mission of the Association because they provided a discrete space to disseminate Ghadar Party politics, through rousing speeches, recitation of poetry, chants of inquilab zindabad, and eulogies for Udham Singh. For instance, at a February 1942 meeting in Bradford, Karam Singh Overseer proclaimed that Udham Singh "did not care for his own life" and Banta Singh echoed these remarks and entreated all in attendance that "Everybody should be like Udham Singh. If a man dies after shooting a man or two, his name will be inscribed in golden words in the pages of history." Additionally, the meeting displayed a deep distrust of the British military apparatus. Banta Singh noted that Indians had registered for national service but subsequently attempted to attain the status of Conscientious Objector but were instead jailed for insubordination. Chowdry Akbar Ali Khan added to this sentiment by observing that "whenever the British had wanted to make other countries slaves" they had used Indians to do so. "When Indians can fight for another nation to make others slaves," he continued, "then they can fight for themselves" (IPI to Mr. Silver 20 March 1942, IOR/L/PJ/12/645.). Thus, this event allowed IWA members to valorize Udham Singh as an exemplary revolutionary and agent of the Ghadar movement. Moreover, it underscored the Ghadar mission to persuade Indian soldiers to abandon their posts and undermine the British military's imperial project by refusing to maintain the oppression other subject nations.

In addition to exalting Udham Singh and imploring Indians to disengage from imperialist military campaigns, the Indian Workers' Association closed ranks with the Ghadar Party by soliciting funds for the Desh Bhagat Parwar Sahaik Committee, which distributed money to the families of those imprisoned or executed for participating in the Ghadar and Akali movements in Punjab. As mentioned earlier, Karam Singh Chima, Charan Singh's uncle, worked closely with this Fund in Punjab and the Indian Workers' Association would have emerged as the "Indian Political Prisoners' Defence Committee" had the war not slowed its development. As early as 1934, the Ghadar Party made special requests for funds, having already distributed nearly Rs. 100,000 from 
1922-1934, noting that "it is our foremost purpose to help the orphans and the aged parents of those national heroes who sacrificed themselves to have us freed and to make us happy" (Hindustan Ghadr October 1934, IOR/L/PJ/12/757). By 1942, the IWA took up this initiative and remitted Rs. 2,000 to aid "the families of the Ghadr party leaders" (IPI to Mr. Silver 20 March 1942, IOR/L/PJ/12/645). However, support for the Fund was not uncontroversial. Later that year, the Coventry IWA leadership unilaterally sent "considerable sums" to India without the input of the membership. Evidently, some argued that such money should be spent primarily on programs to improve conditions for Indians in Britain, which was a foundational, if competing, concern for the organization ("Indian Notes" 14 November 1942, IOR/L/PJ/12/646). Yet, factional disputes notwithstanding, the IWA continued to send support to the Desh Bhagat Parwar Sahaik Committee for the duration of the war.

In 1945, having taken some time to establish itself within the landscape of Indian organizations in Britain, the Coventry IWA brought out a newsletter titled Azad Hind, or "Free India." Under the direction of Kartar Singh Nagra and Vidya Parkash Hansrani, the paper adopted the militant anticolonialism detailed in other Ghadar Party publications, making it, in the eyes of the British intelligence apparatus, "as extreme as anything which has yet appeared in this country in any Indian language" ("Indian Activities" 1 June 1945, IOR/L/PJ/12/646). Indeed, during a meeting of the leftwing Federation of Indian Associations in Great Britain on 14 April 1946, Kartar Singh Nagra stated that Azad Hind was modeled on the Hindustan Ghadr and that he hoped to emulate the latter (IPI to David Petrie 18 April 1946, HO 45/25460). An evocative example of this confluence can be seen in the reprinting of Banka Singh's hagiographic verse eulogizing Udham Singh as "Bawa," which had been previously published in Ghadar (Azad Hind December 1945, HO 45/25460; Hindustan Ghadr August 1940, IOR/L/PJ/12/758).

The violent anticolonial rhetoric of the paper, which circulated in "the London area, the Midlands and the industrial North," won it the attention of MI5 and, later, the Home Office sought to bring charges against it. However, as one government minister lamented, "it was doubted whether, in the event of a prosecution, an English jury could be convinced that the questionable matter amounted, in fact, to incitement to murder" (Minute 23 January 1946, HO 45/25460). In any case, the fears that "a second Udham Singh should arise" due to the encouragement of the paper, led to its characterization as "insidious and poisonous propaganda which aims at corrupting the political views of the working-class Indian in this country and at instilling revolutionary and terrorist ideas" (David Petrie to Alexander Maxwell 15 January 1946, HO 45/25460.). The national distribution of Azad Hind, which was facilitated by the pockets of anticolonial radicalism that had emerged out of the formation of the Indian Workers' Association, helped it to become one of the most prominent instruments for introducing Ghadarite militancy to hundreds of working-class Indians in Britain. 


\section{Conclusion}

The "typical Ghadar outlook," a trait that the intelligence community in Britain attributed to many early Indian Workers Association activists, is not capacious enough to easily apply to all prospective Indian agitators in Britain equally. Ordinarily, this trait was assigned as a kind of fait accompli in discussions of radical Punjabis from Hoshiarpur or Jalandhar - sites of regular anticolonial agitation throughout the interwar period. However, the category also applies more generally to Punjabis who were sympathetic to the aims and methods of interwar iteration of the Ghadar Party. It was a shorthand for those who trafficked in Ghadar Party publications and those of sibling organizations, such as the Kirti-Kisan Party or the Communist Party of India. As Maia Ramnath has shown, Ghadar was sustained by a confluence of political and social movements in the years after its 1914 Ailan-i-Jang - its declaration of war. It was neither exclusively a Punjabi movement or only a movement for national independence. In the midst of the Second World War, the "typical Ghadar outlook" is an evocative, and perhaps intentionally limited, method of naming a form of radical anticolonialism that had travelled back and forth between North America, Europe, and India for decades finally taking root at the centre of empire.

It is fitting, therefore, to return to the beginning and revisit Udham Singh's failed trip to the Leicester Square Theatre. The Robeson film that he had sought out on the day of the assassination, The Proud Valley, is emblematic of the revolutionary politics of the Ghadar movement globally and in Britain specifically. The film, which had opened just a few days earlier, chronicles David Goliath (Paul Robeson), an African American sailor, as he takes work in a Welsh coal mine, joins their choir, and forges friendships with the crew. Yet, as if to suggest that racial and labour solidarity were inapposite, Graham Greene complained in The Spectator that "too many red herrings scent the story lines...colour prejudice is dragged in for the sake of Mr. Paul Robeson who plays the part of a big black Pollyanna" (Greene 1940). But The Proud Valley was a unique achievement in its day. The "colour prejudice" that Greene lamented, was indeed a critical response to the racial anxieties, best encompassed when a white miner exclaimed "well, damn and blast it, man, aren't we all black down in that pit" (The Proud Valley Ealing Studios 1940)? Moreover, having lived in the Soviet Union in the mid-1930s, the peak of Ghadar enrolment in the University of the Toilers of the East, The Proud Valley was a testament to Paul Robeson's radical sensibilities. Indeed, if not for the outbreak of war in 1939, which necessitated a changed ending, as Matthew Sweet $(2005$, 172) has acknowledged, The Proud Valley "would have been the most uncompromisingly Marxist picture ever produced in Anglophone cinema." Thus, though Udham Singh arrived too early, this film's representation of anti-racist solidarity and militant worker mobilization were an apt corollary to the revolutionary anti-Imperialism of the Ghadar movement.

This article has argued that Punjabi migrant workers' political radicalization in Britain was made manifest the memorialisation of Udham Singh in globally circulated Ghadarite literature. The Indian Workers' Association emerged at the intersection of Punjabi militancy, the British Left, 
and the struggle for national liberation. Its engagement with political violence, racial discrimination, and anticolonialism was rooted in the migrant experience and the example of the Ghadar Party. Though the politics of Indian workers in Britain has often been characterized as narrowly nationalist, a critique of imperialism was clearly articulated by representatives of the Federation of Indian Associations in Great Britain, whose leadership derived from the IWA. In 1946, a Subject People's Conference was convened to protest against "the reimposition of Imperialism" in Southeast Asia which was a joint effort of the Federation of Indian Associations in Great Britain, the Pan African Conference, and the Independent Labour Party ("Indian Societies in the UK" 6 June 1946, IOR/L/PJ/12/646). Such a commitment to emancipatory politics was the foundation on which Indian migrant workers, who arrived in Britain by the thousands in the 1950s and 1960s, would anchor far left politics and industrial action in London and the Midlands throughout the postwar period and era of deindustrialization.

\section{References}

\section{Archival Sources}

The National Archives, Kew

Home Office

Disturbances: Indian Workers Association: 'inflammatory' tone of Azad Hind (Quit India), a bilingual monthly in Punjabi and Urdu.1945-1951. HO 45/25460.

Criminal: Singh, Udham Convicted at Central Criminal Court (CCC) on 5 June 1940 for murder and sentenced to death. HO 144/21445.

\section{Metropolitan Police}

Lascar Deserters. Aliens Registration Office. 1931-1938. MEPO 2/5064.

Murder of Sir Michael Francis O'Dwyer by Udham Singh at Caxton Hall, Westminster, on 13 March, 1940. MEPO 3/1743.

India Office Records and Private Papers, British Library

Public and Judicial Department 
Grant of passport facilities to Indians of limited means to come to UK as pedlars etc. 12 Nov 192916 Oct 1939. IOR/L/PJ/7/1007, file 719 .

Indian Communist Party: activities of agents of Manabendra Nath Roy in India. Jan 1923-Jan 1929. IOR/L/PJ/12/54, file 4968(C)/21.

Influence of communism on Indian political organisations in UK. May-Jul 1923. IOR/L/PJ/12/143, file $6841(\mathrm{a}) / 23$.

The Ghadr Party in USA and Canada. Jan 1936-Jun 1944. IOR/L/PJ/12/284, file 1392/25.

Kirti, communist newspaper of Ghadr Party. Jun 1929-Dec 1939. IOR/L/PJ/12/300

IPI reports on Indians in North and South America: the Ghadr Party. Apr 1934-Nov 1939. IOR/L/PJ/12/285, file 1392(A)/25.

IPI reports on Indians in North and South America: the Ghadr Party. Feb 1940-Nov 1948. IOR/L/PJ/12/286, file 1392(A)/25.

Activities of Gurmukh Singh and Rattan Singh alias Isher Singh, Ghadr Party. Jan 1935-Jan 1940. IOR/L/PJ/12/288, file 1392(c)/25.

Indian Workers' Union or Association: reports on members and activities. Jan 1942-Jul 1947. IOR/L/PJ/12/645.

IPI notes on Indian organisations in UK. Apr 1942-Jun 1946. IOR/L/PJ/12/646, file 720/42.

Reports, summaries and translations of Hindustan Ghadr; Ghadr Party activities in USA. Oct 1934-Dec 1937. IOR/L/PJ/12/757, file 995/24.

Reports, summaries and translations of Hindustan Ghadr; Ghadr Party activities in USA. Nov 1937-Dec 1944. IOR/L/PJ/12/758.

Political and Secret Department

Ghadr Party Activities. 27 March 1931-28 Aug 1934. IOR/L/PS/12/1588 Coll 3/35.

Official Publications 
Intelligence Bureau, Government of India. The Ghadr Directory, containing the names of persons who have taken part in the Ghadr movement in America, Europe, Africa and Afghanistan as well as India. New Delhi: Intelligence Bureau, 1934. V/27/262/6. IOR.

Bancroft Library, University of California, Berkeley

South Asians in North America Collection (SANA)

Singh, Rattan. “A Brief History of the Hindustan Gadar Party,” BANC MSS 2002/78, Box 13.

Birmingham Archives and Heritage Service, Library of Birmingham, UK

Papers of Avtar Jouhl and the Indian Workers Association

India Office Public and Judicial Department papers. 1936-1940. MS 2142/B/3/3

\section{Secondary Sources}

Ahuja, Ravi. 2008. "Networks of subordination -- networks of the subordinated: The ordered spaces of South Asian maritime labour in an age of imperialism (c. 1890-1947).” In The Limits of British Colonial Control in South Asia: Space of Disorder in the Indian Ocean Region, eds. Ashwini Tambe and Harald Fischer-Tiné. New York: Routledge.

Ballard, Roger and C. Ballard. 1977. "The Sikhs: The Development of South Asian Settlements in Britain." in J.L. Watson (ed.) Between two cultures. Oxford: Blackwell.

Callaghan, John. 1997. "Colonies, Racism, the Cpgb and the Comintern in the Inter-War Years." Science \& Society, 61(4), 513-525.

Clark, David. 1975. "Recollections of resistance: Udham Singh and the IWA.” Race \& Class 17 (1): 75-77. DOI 10.1177/030639687501700108

Davis, Mike. 2002. Late Victorian Holocausts: El Nino Famines and the Making of the Third World. London: Verso.

Fenech, Louis E. 2002. "Contested Nationalisms; Negotiated Terrains: The Way Sikhs Remember Udham Singh 'Shahid' (1899-1940).” Modern Asian Studies. 36 (4): 827-870. DOI 10.1017/S0026749x02004031. 
Fox, Richard G. 1985. Lions of the Punjab: culture in the making. Berkeley: University of California Press.

Gandhi, Leela. 2006. Affective Communities: Anticolonial Thought, Fin-de-Siècle Radicalism, and the Politics of Friendship. Durham: Duke University Press.

Greene, Graham. 1940. “The Cinema: Proud Valley. At the Leicester Square. Dead Man's Shoes. At the Regal." The Spectator. 164: 361

Hiro, Dilip. 1973. Black British, White British. New York: Monthly Review Press.

Josh, Sohan Singh. 1977. Hindustan Gadar Party: a short history. New Delhi: People's Publishing House.

Juergensmeyer, Mark. 1977. “The Ghadar syndrome: nationalism in an immigrant community." Punjab Journal of Politics. 1 (1): 1-22.

Lewis, Earl. 1995. "To Turn as on a Pivot: Writing African Americans into a History of Overlapping Diasporas." The American Historical Review. 100 (3): 765. DOI $10.2307 / 2168604$

Mann, Michael. 2015. South Asia's Modern History: Thematic Perspectives. New York: Routledge.

Mukherjee, Mridula. 2004. Peasants in India's Non-violent Revolution: Practice and Theory. New Delhi: SAGE.

Mukherji, S. Ani. 2011. "The Anticolonial Imagination: The Exilic Productions of American Radicalism in Interwar Moscow.” PhD diss., Brown University. ProQuest (3479707)

Puri, Harish K. 1983. Ghadar movement: ideology, organisation \& strategy. Amritsar: Guru Nanak Dev University Press.

Ramnath, Maia. 2011. Haj to Utopia: How the Ghadar Movement Charted Global Radicalism and Attempted to Overthrow the British Empire. Berkeley: University of California Press.

Raza, Ali. 2013. "Separating the Wheat from the Chaff: Meerut and the Creation of 'Official' Communism in India." Comparative Studies of South Asia, Africa and the Middle East. 33 (3): 316-330. DOI 10.1215/1089201x2378112. 
Sharma, Shalini. 2010. Radical Politics in Colonial Punjab: Governance and Sedition. London: Routledge.

Sherwood, Marika. 1996. "The Comintern, the CPGB, Colonies and Black Britons, 1920-1938." Science \& Society, 60(2), 137-163.

Singh, Navtej. 2007. "Reinterpreting Shaheed Udham Singh.” Economic and Political Weekly. 42 (48): 21-23.

Sivanandan. A. 1981. "From Resistance to rebellion: Asian and Afro-Caribbean struggles in Britain.” Race \& Class 23 (2-3): 111-152. DOI 10.1177/030639688102300202.

Smith, Evan. 2008. "Class Before Race: British Communism and the Place of Empire in Postwar Race Relations". Science \& Society. 72 (4): 455-481.

Sohi, Seema. 2014. Echoes of Mutiny: Race, Surveillance, and Indian Anticolonialism in North America. New York: Oxford University Press.

Stadtler, Florian. 2012. “'For every O'Dwyer...there is a Shaheed Udham Singh': The Caxton Hall Assassination of Michael O'Dwyer." In South Asian Resistances in Britain, 1858-1947, edited by Rehana Ahmed and Sumita Mukherjee, 19-32. New York: Continuum.

Sweet, Matthew. 2005. Shepperton Babylon: the lost worlds of British cinema. London: Faber and Faber.

Tatla, Darshan Singh. 1999. The Sikh Diaspora: The Search for Statehood. Seattle: University of Washington Press.

Upadhyay, Nishant, ed. 2014. Special Issue: Sikh Formations: Religion, Culture, Theory 10 (1). 